\title{
KLASIFIKASI DAERAH KABUPATEN/KOTA DI PROPINSI MALUKU BERDASARKAN TIPOLOGI KLASSEN
}

ISSN : 2656-3363-Vol.1 No 2-2019

\author{
BY : \\ ( PAULUS LARATMASE ) \\ DOSEN STIE-SAUMLAKI
}

\begin{abstract}
This study aims to determine the classification of regions (districts / cities) in Maluku Province based on the Klassen typology. This research was conducted in Maluku Province with the consideration that Maluku is one of the provinces with a GDP level, PDR growth rate, and a relatively small GDP per capita compared to the Provinces in Indonesia, but with the potential it has a possibility to increase economic growth. This study uses secondary data in the form of data on Gross Regional Domestic Product (GRDP) on the basis of constant prices, both growth rates, contributions and GDP per capita. The data collection method used, namely the documentation method, then carried out the analysis using the Klassen Typology analysis tool, Based on the results of the study there were 2 Cities and 1 District classified as fast-developing and fast-growing regions, fast developing regions consisting of two Regencies, Districts / Cities classified in the classification of advanced but depressed areas / potential to be left behind consists of 3 Three Districts. Regency / City Region classified as relatively underdeveloped region consists of 3 Districts.
\end{abstract}

Key words: Klassen Typologi

\section{PENDAHULUAN}

Otonomi daerah berdasarkan UU nomor 32 Tahun 2004, daerah diberi kewenangan dan peluang yang luas bagi penyelenggaraan fungsi pemerintahan, kecuali dalam bidang politik luar negeri, pertahanan, keamanan, Yustisi, moneter dan fiskal Nasional, serta agama. Untuk itu perlu adanya penajaman orientasi pembangunan yang berbasis pada potensi daerah guna dapat memberikan 
kontribusi bagi pembentukan PDRB Masing-masing daerah sehingga setiap daerah mampu menciptakan daya saing daerahnya masing-masing dengan tujuan untuk meningkatkan kesejahteraan masyarakyat setempat. Berdasarkan pada kemampuan itu maka pemerintah daerah benar-benar dapat menjadi pelaku utama pembangunan di daerahnya, sedangkan pemerintah pusat bertindak sebagai fasilitator dan koordinator pembangunan nasional.

Pelaksanaan Otonomisasi Daerah di Indonesia dititikberatkan pada Pemerintah Kabupaten/Kota, sehinggah diharapkan mampu mandiri di dalam menyelenggarakan pemerintahan, menentukan kebijakan pembangunan serta pendanaan. Kondisi ini akan mampu meningkatkan kemampuan dalam menggali dan mengelola sumber-sumber/potensi ekonomi yang dimiliki daerah sehinggah ketergantungan pada pemerintah pusat di usahakan seminimal mungkin.

Dalam membiayai pelaksanaan fungsi pemerintahan, pemerintah daerah mempunyai sumber-sumber penerimaan yang tercantum dalam UU Nomor 33 Tahun 2014 tentang perimbangan keuangan antara pemerintah pusat dan pemerintah daerah. Untuk meningkatkan pertumbuhan Ekonomi suatu daerah maka pemerintah daerah secara Universal harus memegang peranan aktif untuk meningkatkan penerimaan sektor-sektor ekonomi (PDRB) yang ada di daerah masing-masing.

Propinsi Maluku merupakan salah satu daerah propinsi yang memiliki 11 daerah Kabupaten/Kota, terdiri atas 9 Kabupaten dan 2 Kota, merupakan salah satu daerah Provinsi yang mempunyai jumlah penduduk miskin relativ banyak di Indonesia, namun memiliki perkembangan tingkat perekonomian (PDRB, laju pertumbuhan dan PDRB per Kapita) relative cukup baik. Adapun perkembangan perekonomian daerah propinsi Maluku ditunjukkan dalam table berikut.

Tabel 1.

PDRB, Laju Pertumbuhan PDRB, dan PDRB per Kapita Provinsi Maluku

\begin{tabular}{|c|c|c|c|}
\hline Tahun & $\begin{array}{c}\text { PDRB (miliar } \\
\text { Rp) }\end{array}$ & $\begin{array}{c}\text { Laju Pertumbuhan } \\
\text { PDRB }(\%)\end{array}$ & $\begin{array}{c}\text { PDRB Per Kapita } \\
\text { (Juta Rp) }\end{array}$ \\
\hline 2011 & $19.597 .390,14$ & 6,34 & 12,48 \\
\hline 2012 & $20.999 .878,81$ & 7,16 & 13,13 \\
\hline
\end{tabular}




\begin{tabular}{|l|l|l|l|}
\hline 2013 & $22.121 .911,47$ & 5,34 & 13,58 \\
\hline 2014 & $23.570 .319,69$ & 6,55 & 14,22 \\
\hline 2015 & $24.921 .708,33$ & 5,73 & 14,78 \\
\hline 2016 & $26.377 .990,50$ & 5,84 & 15,38 \\
\hline 2017 & $27.912 .670,36$ & 5,81 & 16,00 \\
\hline \multicolumn{2}{|c|}{ Rerata } & 6,11 & 14,22 \\
\hline
\end{tabular}

Sumber : BPS Propinsi Maluku (Propinsi Maluku dalam angka,/data diolah)

Dari Tabel diatas diketahui bahwa PDRB dan PDRB Per Kapita Propinsi Maluku selalu mengalami kenaikan dari tahun ketahun selama periode tahun 2011-2017, namun tidak pada laju pertumbuhan PDRB mengalami fluktuasi yang mana pada tahun 2013 laju pertumbuhan PDRB mengalami penurunan yakni 5,34 \%, yang sebelumnya laju pertumbuhan PDRB Propinsi Maluku pada tahun 2012 sebesar 7,16 \%, demikian halnya pada tahun 2015 dan 2017 mengalami penurunan setelah pada tahun 2014, 2016 Laju Pertumbuhan PDRB Propinsi Maluku mengalami kenaikan yakni 6,55 \%, dan 5,84 \%. Berdasarkan latar belakang yang telah dikemukakan, maka penulis mencoba untuk merumuskan masalah penelitian, yakni bagaimana klasifikasi daerah (Kabupaten/ Kota) di Propinsi Maluku Tahun 2011-2017, berdasarkan Tipologi Klassen.

Suatu wilayah dikatakan mengalami pertumbuhan ekonomi apabila terjadi peningkatan Produk Domestik Regional Bruto (PDRB) riil di wilayah tersebut. Apabila tingkat pertumbuhan ekonomi bernilai negatif berarti kegiatan perekonomian menunjukkan penurunan, sebaliknya jika tingkat pertumbuhan ekonomi tersebut bernilai positif berarti kegiatan perekonomian mengalami peningkatan. (Arsyad,2010). Strategi Pembangunan Seimbang diartikan sebagai (Arsyad,2010) pembangunan berbagai jenis industri secara bersamaan sehingga industri tersebut saling menciptakan pasar bagi yang lain. Hal ini juga dapat diartikan sebagai keseimbangan pembangunan di berbagai sektor. Menurut Sumitro (1994), pertumbuhan ekonomi bersangkut paut dengan proses pembangunan yang berdimensi tunggal dan diukur dengan meningkatnya hasil produksi dan hasil pendapatan. Perbedaan pertumbuhan ekonomi akan membawa masing-masing daerah membentuk suatu pola pertumbuhan dimana dapat digolongkan dalam klasifikasi tertentu, untuk mengetahui potensi relative 
perekonomian suatu daerah dapat dilihat dengan menggunakan analisis Klassen Typology.

Konsep dasar dari Teori in ditunjukkan oleh kondisi daerah-daerah di sekitar kota yang semakin buruk. Kekuatan pasar cenderung mempengaruhi kesenjangan antara daerah-daerah tersebut. Daerah yang maju mengalami akumulasi keunggulan kompetitif dari pada daerah-daerah yang lain. Hal inilah yang disebut oleh Myrdal sebagai backwash effect (Arsyad, 2010).

\section{Klassen Typology (Tipologi Klassen)}

Adalah alat ukur yang digunakan untuk mengetahui gambaran tentang pola dan struktur pertumbuhan ekonomi masing-masing daerah. Tipologi Klassen pada dasarnya membagi daerah berdasarkan dua indikator utama, yaitu pertumbuhan ekonomi daerah dan pendapatan per kapita daerah. Melalui analisis ini diperoleh empat karateristik pola dan struktur pertumbuhan ekonomi yang berbeda, yaitu: daerah cepat-maju dan cepat-tumbuh (high growth and high income), daerah maju tapi tertekan (high income but low growth), daerah berkembang cepat (high growth but income), dan daerah relatif tertinggal (low growth and low income) (Kuncoro dan Aswandi, 2002) :

a. Daerah cepat-maju dan cepat-tumbuh, adalah daerah Kabupaten/Kota yang memiliki tingkat pertumbuhan ekonomi dan pendapatan per kapita yang lebih tinggi dibanding rata-rata daerah Propinsi.

b. Daerah maju tapi tertekan, adalah daerah Kabupaten/Kota yang memiliki pendapatan per kapita lebih tinggi, tetapi tingkat pertumbuhan ekonominya lebih rendah dibanding rata-rata Provinsi.

c. Daerah berkembang cepat, adalah daerah Kabupaten/Kota yang memiliki tingkat pertumbuhan tinggi, tetapi tingkat pendapatan per kapita lebih rendah dibanding rata-rata Propinsi.

d. Daerah relatif tertinggal, adalah daerah Kabupaten/Kota yang memiliki tingkat pertumbuhan ekonomi dan pendapat per kapita yang lebih rendah dibanding rata-rata Provinsi. 
Dikatakan "tinggi" apabila indikator di suatu kabupaten/kota lebih tinggi dibandingkan indikator di Provinsi. Dan digolongkan "rendah" apabila indikator di suatu kabupaten/kota lebih rendah dibandingkan indikator di Provinsi.

\section{Hasil Penelitian Sebelumnya}

1. Hairul Aswandi dan Mudrajat Kuncoro (2002). Berdasarkan Analisis Tipologi Klassen, Sepuluh Kabupaten/Kota di Propinsi Kalimantan Selatan, dapat diklasifikasikan sebagai berikut. Daerah cepat maju dan cepat tumbuh terdiri atas Kabupaten Kota Baru; Daerah maju tapi tertekan terdiri atas Kota Banjarmasin, dan Kabupaten Banto Kuala; Daerah berkembang cepat terdiri atas Kabupaten Tabalong, Hulu Sungai Utara, dan Tapin; Daerah relatif tertinggal terdiri atas Kabupaten Banjar, Tanah Laut, Hulu Sungai Selatan, dan Hulu Sungai Tengah.

2. Elia Radianto (2003). Berdasarkan Analisis Tipologi Klassen, Lima Kabupaten/Kota di Propinsi Maluku, dapat diklasifikasikan sebagai berikut. Tidak ada Kabupaten/Kota yang termasuk dalam klasifikasi daerah cepat maju dan cepat tumbuh; Daerah maju tetapi tertekan terdiri atas Kota Ambon; Daerah Berkembang Cepat terdiri atas Kabupaten Maluku Tenggara, dan Maluku Tenggara Barat; Daaerah relative tertinggal terdiri atas Kabupaten Maluku Tengah, dan Pulau Buru.

3. I Made Wardana (2007). Berdasarkan Analisis Tipologi Klassen, Sembilan Kabupaten/Kota di Propinsi Bali, dapat diklasifikasikan sebagai berikut. Daerah cepat maju dan cepat tumbuh terdiri atas Kabupaten Badung, dan Kota Denpasar; Tidak ada Kabupaten/Kota yang termasuk dalam klasifikasi daerah maju tetapi tertekan; Daerah berkembang cepat terdiri atas Kabupaten Jembrana, Tabanan, Gianyar, Klungkung, dan Buleleng; Daerah relative tertinggal terdiri atas Kabupaten Bangli, dan Karang Asem.

4. Ernawati Pasaribu (2009). Berdasarkan Analisis Tipologi Klassen, Empat Belas Kabupaten/Kota di Propinsi Kalimantan Tengah, dapat 
diklasifikasikan sebagai berikut. Daerah cepat maju dan cepat tumbuh terdiri atas KotaWaringin Barat, dan Kotawaringin Timur; Daerah maju tetapi tertekan terdiri atas Kabupaten Sukamara, Lamandau, Seruyan, Katingan, Barito Utara, dan Murung raya; Tidak ada Kabupaten/Kota yang termasuk dalam klasifikasi daerah Berkembang Cepat; (4) Daerah relatif tertinggal terdiri atas Kota Palangkaraya, Gunung Mas, Barito Timur, Barito Selatan, Kapuas, dan Pulang Pisau.

5. Henry Sarnowo (2010). Berdasarkan Analisis Tipologi Klassen, Empat Belas Kabupaten/Kota di Propinsi Jawa Tengah, dapat diklasifikasikan sebagai berikut. Daerah cepat maju dan cepat tumbuh terdiri atas Kabupaten Cilacap, Sukoharjo, Karanganyar,Kudus, Kota Surakarta, dan Kota Semarang; (2) Daerah maju tetapi tertekan terdiri atas Kabupaten Semarang, Kendal, Magelang, dan Kota Pekalongan; (3) Daerah Berkembang Cepat terdiri atas Kabupaten Purbalingga, Purworejo, Magelang, Sragen, Tegal, Brebes, Kota Salatiga, dan Kota Tegal; (4) Daerah relatif tertinggal terdiri atas Kabupaten Banyumas, Banjarnegara, Kebumen, Wonosobo, Boyolali, Klaten, Wonogiri, Grobogan, Blora, Rembang, Pati, Jepara, Demak, Temanggung, Batang, Pekalongan, Pemalang.

\section{METODE PENELITIAN}

Variabel yang digunakan dalam penelitian ini adalah :

a. Produk Domestik Regional Bruto (PDRB) menurut Kabupaten/Kota di Propinsi Maluku tahun 2011-2017.

b. Produk Regional Bruto (PDRB) per Kapita ADHK (Atas Dasar Harga Konstan) 2010 menurut Kabupaten/Kota di Propinsi Maluku tahun 2011-2017.

c. Laju Pertumbuhan PDRB ADHK 2010 menurut Kabupaten/Kota di Propinsi Maluku tahun 2011-2017. 
Data yang digunakan dalam penelitian ini adalah data sekunder yang diperoleh dari Badan Pusat Statestik (BPS), Baik data di tingkat Propinsi maupun data di tingkat Kabupaten/Kota di Propinsi Maluku.

Alat Analisis

Alat analisis yang digunakan dalam penelitian ini adalah Tipologi Klassen, yaitu alat yang digunakan untuk mengetahui gambaran dan klasifikasi tentang pola dan struktur pertumbuhan Ekonomi masingmasing daerah. Klasifikasi berdasarkan wilayah ditunjukkan dalam diagram berikut berikut ini.

Diagram 1.

Klasifikasi Wilayah berdasarkan Tipologi Klassen

\begin{tabular}{|c|c|c|}
\hline Laju Pertumbuhan (r) & $\begin{array}{c}\mathbf{Y}_{\mathbf{i}}>\mathbf{Y} \\
\text { (tinggi) }\end{array}$ & $\begin{array}{c}\mathbf{Y}_{\mathbf{i}}<\mathbf{Y} \\
\text { (rendah) }\end{array}$ \\
\hline $\mathbf{g}_{\mathbf{i}}>\mathbf{g}$ & per & Tipe I \\
(tinggi) & Daerah cepat & Tipe II \\
maju dan cepat & Daerah \\
tumbuh & berkembang cepat \\
\hline (rendah) & Tipe III & Tipe IV \\
& Daerah maju tapi & Daerah relatif \\
& tertekan (potensial & tertinggal \\
\hline & untuk tertinggal) & \\
\hline
\end{tabular}

Sumber : Arsyad (2010)

Keterangan : 
$\mathrm{g}_{\mathrm{i}}$ : laju pertumbuhan PDRB Kabupaten/Kota i di Propinsi Maluku.

g : laju pertumbuhan PDRB Propinsi Maluku.

yi : PDRB per kapita Kabupaten/Kota i di Propinsi Maluku.

y : PDRB per kapita Provinsi Maluku.

\section{ANALISIS DATA DAN HASIL PENELITIAN}

Berdasarkan data Laju Pertumbuhan PDRB dan PDRB per Kapita Kabupaten/Kota di Propinsi Maluku, maka dapat ditentukan peringkat tinggi atau rendah klasifikasi daerah Kabupaten/Kota terhadap daerah referensi setingkat diatasnya yakni Propinsi Maluku. Dikatakan tinggi apabila laju pertumbuhan PDRB dan PDRB per Kapita daerah Kabupaten/Kota lebih tinggi dibandingkan dari Propinsi, sebaliknya dikatakan rendah apabila laju pertumbuhan PDRB daerah Kabupaten/Kota lebih rendah dibandingkan dengan Propinsi.

Tabel.2

Laju pertumbuhan dan PDRB Per Kapita Kabupaten/Kota di Propinsi Maluku

Tahun 2013-2017

\begin{tabular}{|c|l|c|c|c|c|}
\hline No. & \multicolumn{1}{|c|}{ Kabupaten/Kota } & \multicolumn{2}{|c|}{ Laju Pertumbuhan PDRB } & \multicolumn{2}{|c|}{ PDRB per Kapita } \\
\cline { 3 - 6 } & & Rerata(\%) & $\begin{array}{l}\text { Perbandingan } \\
\text { (Tinggi/Rendah) }\end{array}$ & $\begin{array}{l}\text { Rerata } \\
\text { Ribu } \\
\text { Rp) }\end{array}$ & $\begin{array}{l}\text { Perbandingan } \\
\text { (Tinggi/Rendah) }\end{array}$ \\
\hline 1. & $\begin{array}{l}\text { Kab.MalukuTenggara } \\
\text { Barat }\end{array}$ & 6,14 & Tinggi & 11,55 & Rendah \\
\hline 2. & $\begin{array}{l}\text { Kab. Maluku Barat } \\
\text { Daya }\end{array}$ & 6,78 & Tinggi & 22,15 & Tinggi \\
\hline 3. & $\begin{array}{l}\text { Kab. Maluku } \\
\text { Tenggara }\end{array}$ & 6,06 & Rendah & 15,43 & Tinggi \\
\hline 4. & Kota Tual & 6,16 & Tinggi & 17,13 & Tinggi \\
\hline 5. & Kab. Kepulauan Aru & 5,15 & Rendah & 19,12 & Tinggi \\
\hline 6. & Kab. Maluku Tengah & 5,64 & Rendah & 12,07 & Rendah \\
\hline 7. & $\begin{array}{l}\text { Kab. Seram Bagian } \\
\text { Barat }\end{array}$ & 5,75 & Rendah & 8,88 & Rendah \\
\hline 8. & $\begin{array}{l}\text { Kab. Seram Bagian } \\
\text { Timur }\end{array}$ & 5,27 & Rendah & 15,56 & Tinggi \\
\hline
\end{tabular}




\begin{tabular}{|c|l|c|c|c|c|}
\hline 9. & Kab. Buru & 5,50 & Rendah & 9,51 & Rendah \\
\hline 10. & Kab. Buru Selatan & 5,77 & Tinggi & 11,45 & Rendah \\
\hline 11. & Kota Ambon & 6,63 & Tinggi & 19,53 & Tinggi \\
\hline & Maluku & $\mathbf{6 , 1 1}$ & & $\mathbf{1 4 , 2 2}$ & \\
\hline
\end{tabular}

Sesuai hasil perbandingan dalam table 2. Daerah Kabupaten/Kota tersebut, kemudian dilakukan pengklasifikasian pola pertumbuhan melalui pendekatan Tipologi Klassen, yang hasilnya ditunjukkan pada diagram Tipology Klassen di bawah ini.

Diagram 2.

Klasifikasi daerah Kabupaten/Kota diPropinsi Maluku menurut Tipologi Kassen

\begin{tabular}{|c|c|c|}
\hline (PDRB) per & Yi > Y (tinggi) & $\mathbf{Y} \mathbf{i}<\mathbf{Y} \quad($ rendah $)$ \\
\hline $\begin{array}{c}\text { gi > g } \\
\text { (timari) }\end{array}$ & \begin{tabular}{l}
\multicolumn{1}{c}{ Tipe I } \\
(Daerah cepat Maju \\
dan cepat tumbuh) \\
Kota Ambon \\
Kota Tual \\
Kab. Maluku Barat \\
Daya
\end{tabular} & $\begin{array}{l}\text { Tipe II } \\
\begin{array}{l}\text { (Daerah berkembang } \\
\text { cepat) }\end{array} \\
\text { Kab. MalukuTenggara } \\
\text { Barat } \\
\text { Kab. Buru Selatan }\end{array}$ \\
\hline
\end{tabular}


\begin{tabular}{|c|c|c} 
gi $<$ g \\
\hline (rendah $)$
\end{tabular}

(rendah)
Tipe III Daerah maju tapi tertekan (potensial untuk tertinggal)

Kab. Seram Bagian Timur Kab. Maluku Tenggara

Kab. Kepulauan Aru
Tipe IV

(Daerah relatif tertinggal)

Kab. Maluku Tengah Kab. Seram Bagian Barat Kab. Buru

Hasil Klasifikasi daerah berdasarkan Tipologi Klassen sesuai Diagram 2 di atas menunjukkan bahwa Kabupaten/Kota yang termasuk dalam klasifikasi Daerah Tipe I terdiri dari tiga (3) Daerah, yakni Daerah cepat maju dan cepat Tumbuh yaitu Kota Ambon, Kota Tual, dan Kabupaten Maluku Barat Daya. Kabupaten/Kota yang termasuk dalam klasifikasi daerah Tipe II terdiri dari dua (2) daerah, yakni daerah berkembang cepat yaitu Kabupaten Maluku Tenggara Barat, dan Kabupaten Buru Selatan. Kabupaten/Kota yang termasuk dalam klasifikasi daerah tipe III terdiri dari tiga (3) daerah, yakni daerah maju tapi tertekan (potensial untuk tertinggal) yaitu Kabupaten Seram Bagian Timur, Kabupaten Maluku Tenggara, dan Kabupaten Kepulauan Aru. Sedangkan Kabupaten/Kota yang termasuk dalam klasifikasi wilayah Tipe IV terdiri dari tiga (3) daerah, yakni Daerah relatif tertinggal yaitu Kabupaten Maluku Tengah, Kabupaten Seram Bagian Barat, dan Kabupaten Buru.

\section{KESIMPULAN DAN SARAN}

Berdasarkan hasil penelitian dengan menggunakan analisis Tipologi Klassen dapat ditarik kesimpulan sebagai berikut :

Daerah Kabupaten/Kota yang tergolong dalam dalam klasifikasi daerah Tipe I yaitu daerah cepat maju dan cepat tumbuh terdiri dari tiga daerah (dua kota dan satu Kabupaten). Daerah Kabupaten/Kota yang tergolong dalam dalam klasifikasi daerah Tipe II yaitu daerah berkembang cepat terdiri dari dua daerah (dua Kabupaten). Daerah Kabupaten/Kota yang tergolong dalam klasifikasi daerah Tipe III yaitu daerah maju tapi tertekan/potensial untuk tertinggal terdiri dari Tiga daerah (Tiga Kabupaten). Daerah Kabupaten/Kota yang tergolong dalam 
klasifikasi daerah Tipe IV yaitu daerah relatif tertinggal terdiri dari Tiga daerah (Tiga Kabupaten). Berdasarkan hasil analisis dan kesimpulan yang telah dipaparkan, maka dapat dikemukan saran yang juga dapat dijadikan implikasi kebijakan adalah sebagai berikut.

Kebijakan pengeluaran Pembangunan daerah hendaklah lebih diprioritaskan kepada daerah Kabupaten/Kota yang termasuk dalam klasifikasi daerah relatif tertinggal untuk mendorong pembangunan didaerah tersebut melalui perbaikan prasarana maupun iklim investasi yang kondusif di daerah tersebut, dengan tidak mengabaikan daerah Kabupaten/Kota lainnya yang masih tergolong daerah tipe III, dan II.

\section{DAFTAR PUSTAKA}

Arsyad Lincolin. 2010, Pengantar Perencanaan Pembangunan Ekonomi Daerah, BPFE, Yogyakarta.

Aswandi, Hairul, dan Mudrajad Kuncoro, 2002, Evaluasi Penetapan Kawasan Andalan, Studi Empiris di Kalimatan Selatan 1993-1999, Jurnal Ekonomi dan Bisnis Vol 17, No. 1.

Badan Pusat Statistik Propinsi Maluku, Propinsi Maluku dalam angka 2015, 2018.

Badan Pusat Statistik Kabupaten Maluku Tenggara Barat, MTB dalam Angka 2015, 2018.

Elia. Radianto.2003, Evaluasi Pembangunan Regional Pasca Kerusuhan di Maluku.

Ernawati. Pasaribu. 2009, Tinjauan Kinerja Ekonomi Regional, Studi Empiris Propinsi Kalimantan Tengah 2003-2007.

I Made, Wardana. 2007, Analisa Strategi Pembangunan Propinsi Bali menuju balance Growth, Buletin Studi Ekonomi, Volume 12, No. 2.

Henry, Sarnowo. 2010, Klasifikasi Daerah Kabupaten Kota di Propinsi Jawa Tengah,studi Empiris 2003-2007, Jurnal Bisnis dan Ekonomi, Volume 1, No. 2

Sukirno, Sadono. 2010, Ekonomi Pembangunan. Proses, Masalah dan Dasar Kebijaksanaan. Bima Grafika, Jakarta. 
